\title{
Synthesis of (cinnamate-zinc layered hydroxide) intercalation compound for sunscreen application
}

\author{
Sumaiyah Megat Nabil Mohsin ${ }^{1}$, Mohd Zobir Hussein ${ }^{*}$, Siti Halimah Sarijo², Sharida Fakurazi ${ }^{3,4}$, \\ Palanisamy Arulselvan ${ }^{4}$ and Taufiq-Yap Yun $\mathrm{Hin}^{5}$
}

\begin{abstract}
Background: Zinc layered hydroxide (ZLH) intercalated with cinnamate, an anionic form of cinnamic acid (CA), an efficient UVA and UVB absorber, have been synthesized by direct method using zinc oxide ( $\mathrm{ZnO})$ and cinnamic acid as the precursor.

Results: The resulting obtained intercalation compound, ZCA, showed a basal spacing of $23.9 \AA$ as a result of cinnamate intercalated in a bilayer arrangement between the interlayer spaces of ZLH with estimated percentage loading of cinnamate of about $40.4 \% \mathrm{~W} / \mathrm{w}$. The UV-vis absorption spectrum of the intercalation compound showed excellent UVA and UVB absorption ability. Retention of cinnamate in ZLH interlayers was tested against media usually came across with sunscreen usage to show low release over an extended period of time. MTT assay of the intercalation compound on human dermal fibroblast (HDF) cells showed cytotoxicity of ZCA to be concentration dependent and is overall less toxic than its precursor, $\mathrm{ZnO}$.
\end{abstract}

Conclusions: (Cinnamate-zinc layered hydroxide) intercalation compound is suitable to be used as a safe and effective sunscreen with long UV protection effect.

Keywords: Sunscreen, Zinc layered hydroxide, Zinc oxide, Optical properties, Cytotoxicity

\section{Background}

World Health Organization estimates that 60,000 deaths occur in 2000 from melanoma and other skin cancers due to solar ultraviolet (UV) radiation [1]. Exposure to sunlight is unavoidable as we go about our daily errands. Sunscreen is our last defense against UV radiation. However, protection with sunscreen deemed inadequate due to photodegradation of organic UV absorber in sunscreen products that not only causes decrease in UV protection but also degrades with the occurrence of toxic degradation products. Therefore, development of a new sunscreen formulation is called for, to avoid previously mentioned effects.

Layered metal hydroxides can be categorized into layered double hydroxide (LDH) and layered hydroxide salt (LHS). Several studies have been done on the use of layered metal hydroxide-based sunscreen carrier system,

\footnotetext{
* Correspondence: mzobir@putra.upm.edu.my

${ }^{1}$ Material Synthesis and Characterization Laboratory, Institute of Advanced Technology (ITMA), Universiti Putra Malaysia, Serdang, Selangor 43400 UPM, Malaysia

Full list of author information is available at the end of the article
}

in particular, $\mathrm{LDH}$ [2-4]. $\mathrm{LDH}$ can be represented by the general formula of $\left[\mathrm{M}_{1-\mathrm{x}}^{3+} \mathrm{M}_{\mathrm{x}}^{3+}(\mathrm{OH})_{2}\right]^{\mathrm{z}+} \mathrm{A}_{\mathrm{z} / \mathrm{n}}^{\mathrm{n}} \cdot \mathrm{yH}_{2} \mathrm{O}$ where $\mathrm{A}^{\mathrm{n}-}$ is the interlayer anion, $\mathrm{M}^{2+}$ and $\mathrm{M}^{3+}$ are di- and trivalent metallic cation, respectively [2]. Previous work has shown that cinnamate intercalated into $\mathrm{Zn} / \mathrm{Al} \mathrm{LDH}$ showed excellent UV ray shielding properties [4]. However, to the best of our knowledge application of LHS as host has yet to be explored.

Zinc layered hydroxide (ZLH) is a type of LHS, having the general formula of; $\mathrm{M}^{2+}(\mathrm{OH})_{2-x}\left(\mathrm{~A}^{m-}\right)_{x / m} \cdot n \mathrm{H}_{2} \mathrm{O}$ where $\mathrm{M}^{2+}$ in this case is the metal cation $\mathrm{Zn}^{2+}$ and $\mathrm{A}^{m-}$ is the counter ion [5]. They boast a structure consisting of positively charged layers that can expand or contract depending on the nature of interlayer anions. In recent years, there has been extensive research on the use of ZLH as drug carriers [6,7], slow release herbicides [8], flame retardants [9] and anti-corrosion agents [10]. In this study we further exploit its potential as an efficient host to organic molecules for possible application in sunscreen formulation.

In the present work, we investigated the intercalation of anion, cinnamate, into interlayer galleries of ZLH via 
direct method, as well as properties of the resulting cinnamate-ZLH (ZCA) intercalation compound. Direct method used involved a direct reaction between anion solution and $\mathrm{ZnO}$ precursor. Unlike other LHS synthesis methods like hydrolysis of salts and oxides [11], urea hydrolysis [12], precipitation with alkaline solution [13] and solid state reactions [14], this method is simple, environmentally friendly and economical as it involves fewer steps and fewer chemicals.

By intercalating organic UV absorbers into interlayer galleries of ZLH, the expected advantages are; UV absorber stabilization in interlayer region of a lamellar host to increase photo-stability and decrease degradation of UV absorber, absorption of ultraviolet light rays in UVA and UVB region and the absence of close contact between skin that subsequently eliminates allergy problems [15].

In the present investigation, we selected human dermal fibroblast (HDF) cells as a model to evaluate possible toxicity induction on the cells. Dermal fibroblasts are the most abundant cell in the human skin and represent the primary level of exposure to various environmental and other toxicants. Human skin is the primary anatomical barrier for various pathogens and damage, which acts as an important boundary marker between internal and external environment in the bodily defense system. Hence, the resulting intercalation compound of the present study was investigated for toxicity on human dermal fibroblast cells.

\section{Materials and methods Materials}

Cinnamic acid (98\%) was purchased from Acros (Geel, Belgium). Zinc oxide (99\%) was obtained from PC Laboratory chemicals and was used without further purification. Sodium hydroxide (99\%) from Merck (Darmstadt, Germany), dimethyl sulfoxide (DMSO) and phosphatebuffered solution from Sigma-Aldrich (Missouri, USA) and sodium chloride (99\%) from HmbG Chemicals (Hamburg, Germany) were used without further purifications.

\section{Synthesis of zinc layered hydroxide intercalated with cinnamate}

About $0.2 \mathrm{~g}$ of $\mathrm{ZnO}$ was reacted with $100 \mathrm{~mL}$ of $0.1 \mathrm{~mol} / \mathrm{L}$ $\mathrm{CA}$ solution. The intercalation compound was titrated with $2 \mathrm{~mol} / \mathrm{L} \mathrm{NaOH}$ to the final $\mathrm{pH}$ of 8 before it was magnetically stirred for $5 \mathrm{~h}$ at room temperature. Then it was aged in an oil bath at $70^{\circ} \mathrm{C}$ for $18 \mathrm{~h}$, before being centrifuged and washed with deionized water. The final white solid (ZCA) was dried under vacuum at $70^{\circ} \mathrm{C}$, overnight.

\section{Characterization}

Powder x-ray diffraction (PXRD) patterns were recorded with a XRD-6000 (Shimazdu, Kyoto, Japan) using $\mathrm{CuK}_{\alpha}$ radiation $(\lambda=1.5418 \AA)$ at $30 \mathrm{kV}$ and $30 \mathrm{~mA}$. The data was collected from $2-60^{\circ}$ at a dwell time of $0.5^{\circ} \mathrm{min}^{-1}$. Fourier transform infrared (FTIR) spectra were recorded over the range of $280-4000 \mathrm{~cm}^{-1}$ on a Perkin-Elmer Spectrum 100 (Perkin-Elmer, Waltham, Massachusetts, USA) equipped with universal attenuated total reflectance (ATR) accessory. The carbon and hydrogen content in the intercalation compound were analyzed on a CHNS932 (LECO Instruments, Michigan, USA). The chemical composition of the samples was analyzed for zinc by inductively coupled plasma atomic emission spectrometry (ICP-AES) using a Perkin-Elmer spectrophotometer model Optima 2000DV (Perkin-Elmer, Massachusetts, USA) under standard conditions. Thermogravimetric and differential thermogravimetric analyses (TGA/DTG) were performed on alumina crucibles with a Metter-Toledo instrument model TGA851e (Greifensee, Switzerland) at a heating rate of $10^{\circ} \mathrm{C} \mathrm{min}{ }^{-1}$ in the range of $25-1000^{\circ} \mathrm{C}$ and under nitrogen gas flow of about $50 \mathrm{~mL} \cdot \mathrm{min}^{-1}$. Surface characterization of the materials was carried out using a nitrogen gas adsorption-desorption technique at 77 K with a Micromeritics, ASAP2000 (Georgia, USA). The surface morphology of the samples was observed by a field emission scanning electron microscopy (FESEM) using a ZEISS supra 40VP (Oberkochen, German), and optical measurements were performed on a Shimadzu (Kyoto, Japan) UV-VIS-NIR diffuse reflectance spectrometer (UV-3600 model).

\section{Release of cinnamate from ZCA}

Release of cinnamate anion from ZLH host against time was measured in situ at $\lambda_{\max }=272 \mathrm{~nm}$ using a PerkinElmer UV-VIS spectrometer Lambda 35 (Perkin-Elmer, Massachusetts, USA) by adding $0.2 \mathrm{mg}$ of sample into $3.5 \mathrm{~mL}$ of deionized water, $0.5 \mathrm{~mol} / \mathrm{L} \mathrm{NaCl}$ and $\mathrm{pH} 5.5$ phosphate buffer solution, at room temperature. Data was collected and fitted to zero-, first-, pseudo-second order and parabolic diffusion kinetic models.

\section{Cell culture}

Human dermal fibroblasts were obtained from ATCC (Virginia, USA). Human dermal fibroblast cells were cultured at $37^{\circ} \mathrm{C}$ and $5 \% \mathrm{CO}_{2}$ in high glucose Dulbecco's Modified Eagle Medium (DMEM) (ScienCell Research Laboratories, California, USA) containing $2 \%$ fetal bovine serum, $0.5 \%$ penicillin-streptomycin, $1 \%$ glutamine, and $1 \%$ non-essential amino acids. Cultured cells were passaged using $0.25 \%$ trypsin. At $85 \%$ confluence, cells were harvested using $0.25 \%$ trypsin and were subcultured/seeded into 96-well plates.

\section{Cell viability assay}

Healthy human dermal fibroblast cells (at a density of $1 \times$ $10^{4}$ cells/well) were seeded in a 96-well culture plate. Cultured cells were incubated for $24 \mathrm{~h}$ prior to treatment. 


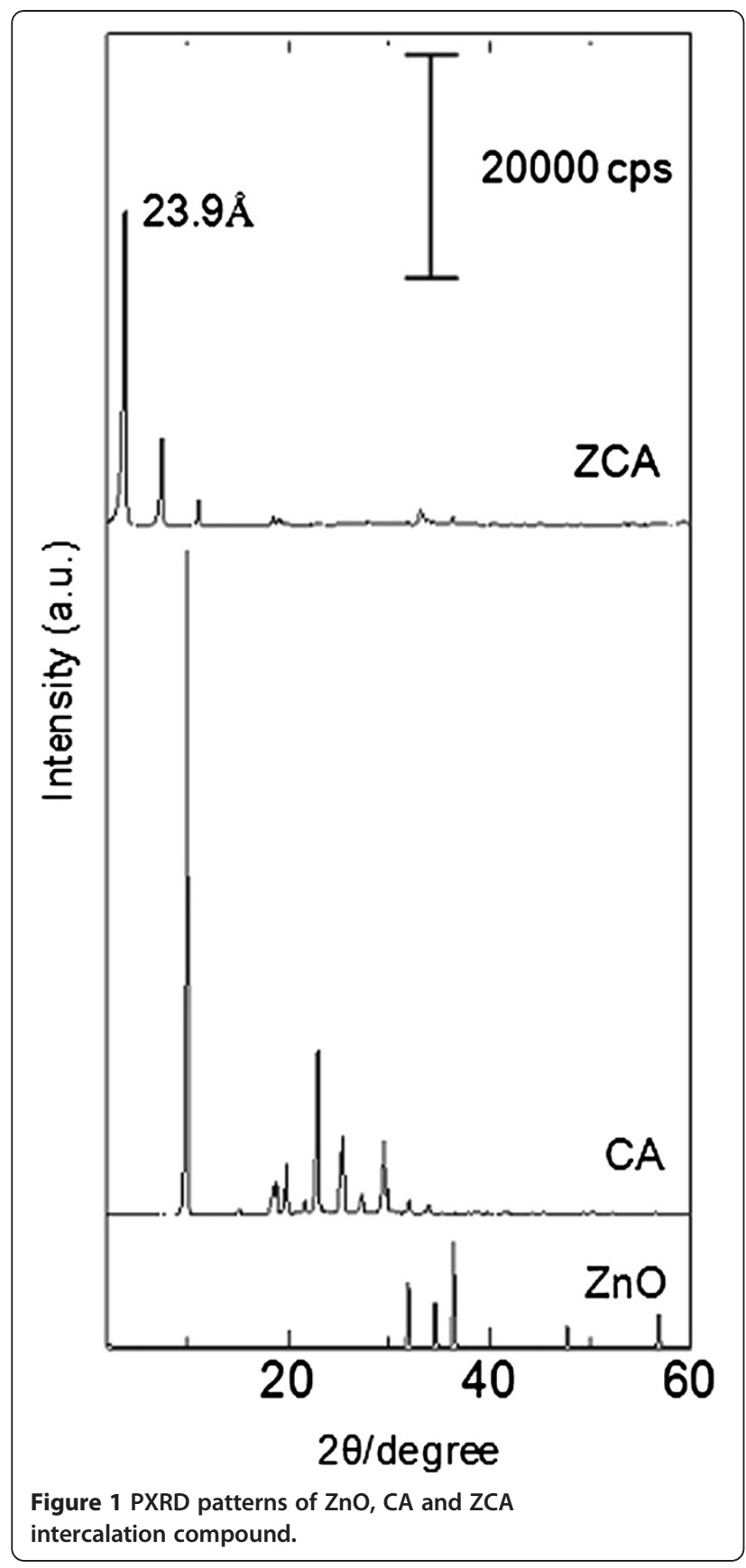

The cells were growing until $80 \%$ confluence, and the media were replaced with different gradient concentrations (from $0.781 \mu \mathrm{g} / \mathrm{mL}$ to $25 \mu \mathrm{g} / \mathrm{mL}$ ) of sample in media for $24 \mathrm{~h}$. After the exposure time, sample containing media were aspirated. The cells were then incubated with freshly prepared MTT solution in fresh medium for $4 \mathrm{~h}$ at $37^{\circ} \mathrm{C}$ until a purple colored formazan product developed. After the incubation time, $100 \mu \mathrm{L}$ DMSO was added to each well to dissolve the formazan crystals. Absorbance of the solution in 96 well plates was measured at 570 and $690 \mathrm{~nm}$ using a Bio-Tek ELISA microplate

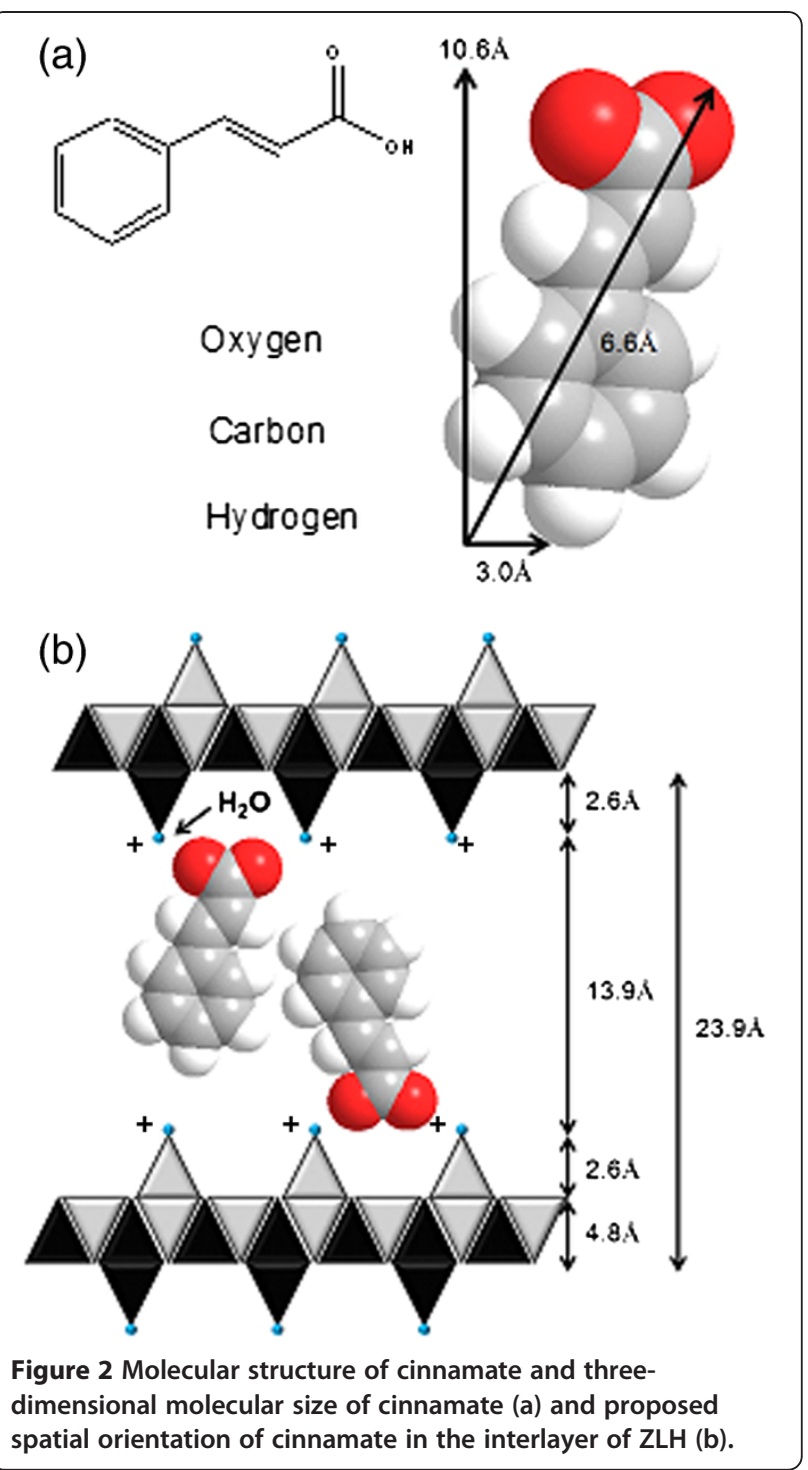

reader EL800 (Vermont, USA). Cell viability was analyzed as a ratio of sample treated cells to untreated cells (control at $0 \mu \mathrm{g} / \mathrm{mL}$ ).

\section{Results and discussion}

$\mathrm{X}$-ray diffraction and spatial orientation of the guest between ZLH interlayers

Figure 1 shows PXRD patterns of $\mathrm{ZnO}, \mathrm{CA}$ and $\mathrm{ZCA}$ intercalation compound synthesized using $0.1 \mathrm{~mol} / \mathrm{L} \mathrm{CA}$. PXRD pattern of $\mathrm{ZnO}$ showed high crystallinity of $\mathrm{ZnO}$ characteristic peaks; especially (100), (200) and (101) reflections. We proposed that the formation of cinnamate$\mathrm{ZLH}$ intercalation compound (ZCA) from $\mathrm{ZnO}$ occurred in three steps through dissociation-deposition mechanism [6,16-19]. The first step, described in Eq. 1, involves hydrolysis of $\mathrm{ZnO}$ in water. When $\mathrm{ZnO}$ particles are immersed in water, the surface of $\mathrm{ZnO}$ hydrolyzes to form 


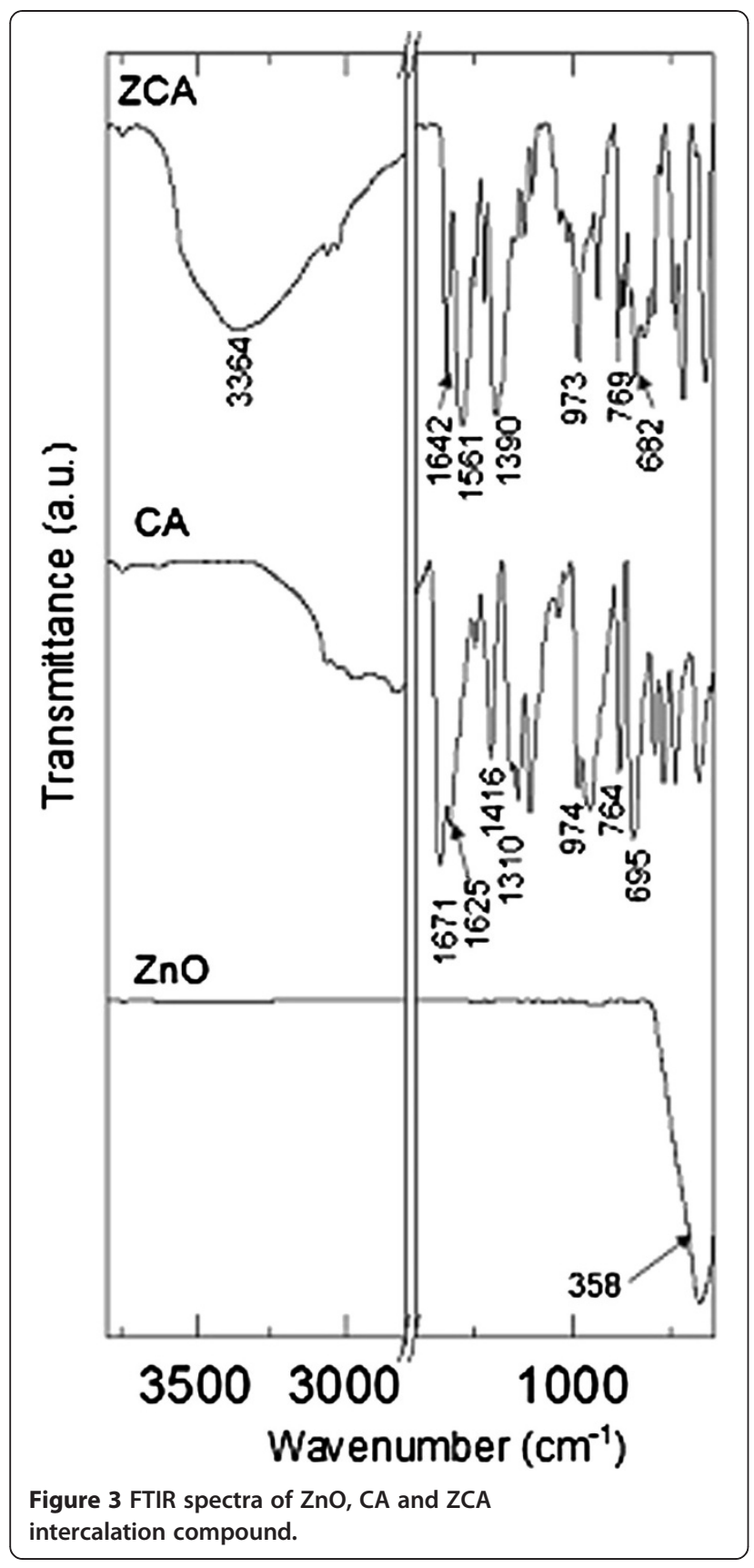

a layer of $\mathrm{Zn}(\mathrm{OH})_{2}$. The layer of $\mathrm{Zn}(\mathrm{OH})_{2}$ formed then become more soluble than $\mathrm{ZnO}$ in the presence of acid to become $\mathrm{Zn}^{2+}$ and $\mathrm{OH}^{-}$(Eq. 2). Finally $\mathrm{Zn}^{2+}$ species, hydroxyls, $\mathrm{H}_{2} \mathrm{O}$ and cinnamate anions $\left(\mathrm{CA}^{-}\right)$in the solution react to generate the layered intercalation compound (Eq. 3). The process is repeated until all the $\mathrm{ZnO}$ phase and the $\mathrm{Zn}(\mathrm{OH})_{2}$ phase has completely converted to the layered compound. The mechanism is described in equations below:

$$
\mathrm{ZnO}+\mathrm{H}_{2} \mathrm{O} \rightleftharpoons \mathrm{Zn}(\mathrm{OH})_{2}
$$
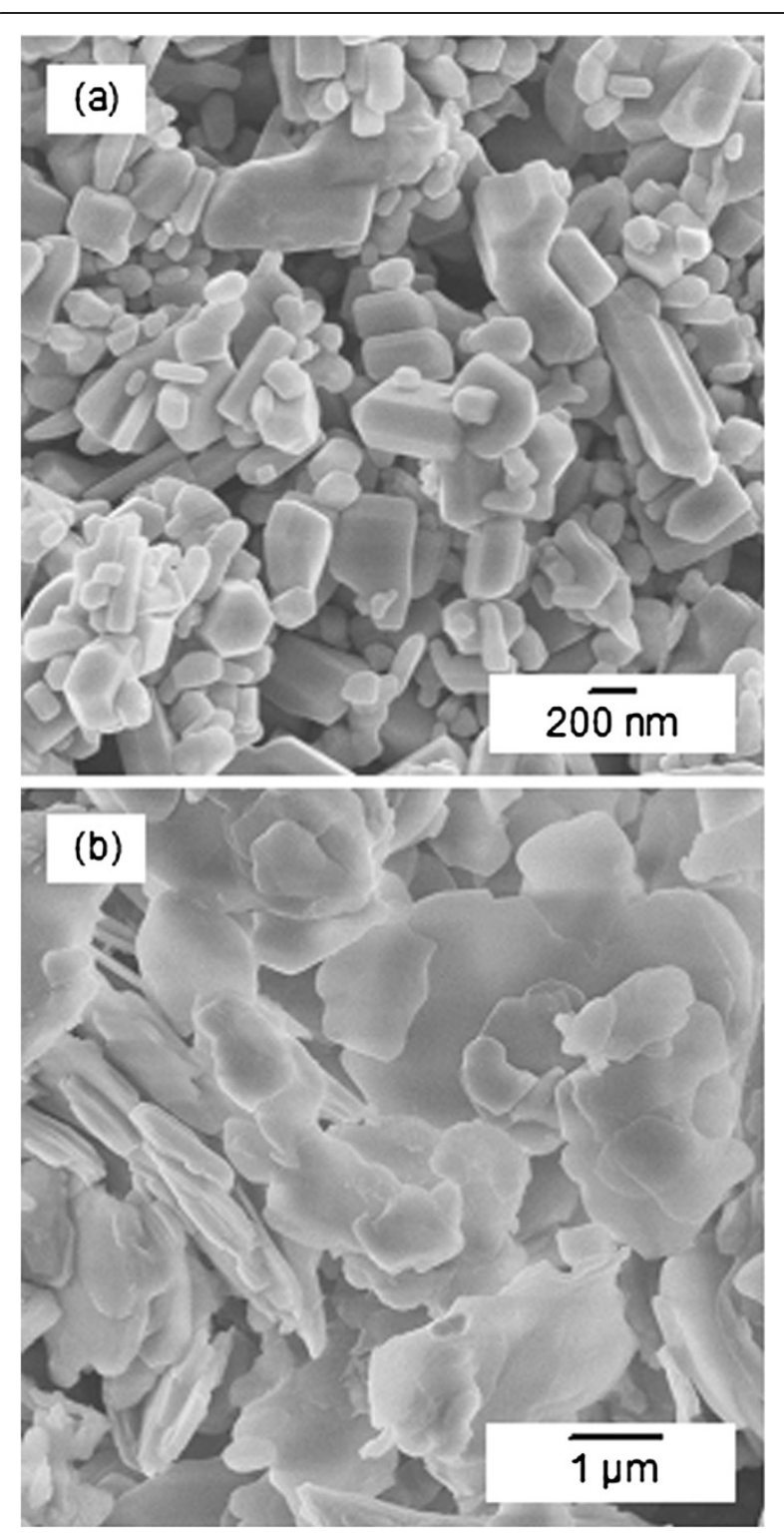

Figure 4 FESEM images of $\mathrm{ZnO}$ at 25,000x magnification (a) and ZCA intercalation compound at 10,000x magnification (b).

$$
\begin{aligned}
& \mathrm{Zn}(\mathrm{OH})_{2} \rightleftharpoons \mathrm{Zn}^{2+}+2 \mathrm{OH}^{-} \\
& \mathrm{Zn}^{2+}+2 \mathrm{OH}^{-}+\mathrm{CA}^{-} \\
& +\mathrm{H}_{2} \mathrm{O} \rightleftharpoons \mathrm{Zn}^{2+}(\mathrm{OH})_{2-x}\left(\mathrm{CA}^{-}\right)_{x} n \mathrm{H}_{2} \mathrm{O}
\end{aligned}
$$

Figure 1(a) shows the PXRD pattern of ZCA synthesized via direct reaction between $\mathrm{CA}$ and $\mathrm{ZnO}$. The average basal spacing of the product was measured to be $23.9 \AA$, based on 3 harmonics. The proposed spatial arrangement of cinnamate within the ZLH interlayer region is based on the basal spacing obtained from PXRD and molecular size of cinnamate anion, as shown in Figure 2(a). Taking into account that the layer thickness is $4.8 \AA$ including $2.6 \AA$ 
Table 1 Physico-chemical properties of $\mathrm{ZnO}$ and ZCA intercalation compound

\begin{tabular}{cccccccc}
\hline Sample & $\mathbf{C}(\%)$ & $\mathbf{H}(\%)$ & ${ }^{\mathbf{a}} \mathbf{Z n}(\% \mathbf{w} / \mathbf{w})$ & ${ }^{\mathbf{b}}$ Anion $(\% \mathbf{w} / \mathbf{w})$ & BET surface area $\left(\mathbf{m}^{\mathbf{2}} / \mathbf{g}\right)$ & BJH pore diameter $(\AA)$ & BJH pore volume $\left(\mathbf{m}^{2} / \mathbf{g}\right)$ \\
\hline $\mathrm{ZnO}$ & - & - & $(80.3)^{*}$ & - & 5 & 91 & 0.01 \\
$\mathrm{ZCA}$ & 29.5 & 3.3 & $38.0^{\mathrm{a}}$ & 40.4 & 13 & 141 & 0.05 \\
\hline
\end{tabular}

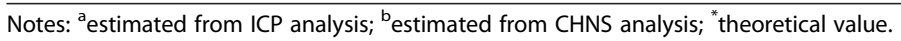

for each zinc tetrahedron [20], the expected gallery height that can be occupied is $13.9 \AA$. Considering the charge density of the layer, anion dimension and assuming that the layer structure remains intact after the intercalation, then cinnamate anions have to orient themselves in a bilayer arrangement by turning the functional group on the opposite side and opposing the fields of aromatic ring mutually by $\pi-\pi$ interactions as shown in Figure 2(b).

Sun et al. reported intercalation of cinnamate anion into $\mathrm{Zn} / \mathrm{Al} \mathrm{LDH}$ as host. The reported basal spacing of intercalation compound is $18.0 \AA$ [4]. Subtracting layer thickness, the gallery available to be occupied is $13.2 \AA$ which is relatively close to the value recorded for ZLH host. Hence we can deduce that cinnamate maintains similar orientation in both hosts. However, the observed basal spacing for ZLH host is significantly larger than what was reported for LDH host. We proposed that ZCA intercalation compound follows LHS type IIb structure which is formed by one quarter of the octahedral zinc cations displaced from main layer to tetrahedral sites located above and below each empty tetrahedron. The base of the tetrahedral share hydroxide groups with the octrahedral layer and the apex is occupied by water molecules. Thus, the tetrahedral sheet accounts for larger basal spacing recorded for cinnamate intercalation in ZLH host.

\section{FTIR spectroscopy}

The FTIR spectra of $\mathrm{ZnO}, \mathrm{CA}$ and $\mathrm{ZCA}$ reacted with $0.1 \mathrm{~mol} / \mathrm{L}$ CA solution are shown in Figure 3. FTIR spectra of pure $\mathrm{ZnO}$ showed a strong peak at $358 \mathrm{~cm}^{-1}$ due to vibration of zinc and oxygen sublattices [21]. FTIR spectra of CA showed strong characteristic vibrations at $1671 \mathrm{~cm}^{-1}$ attributed to $\mathrm{C}=\mathrm{O}$ stretching, 1625 $\mathrm{cm}^{-1}$ to $\mathrm{C}=\mathrm{C}$ stretching, $1310 \mathrm{~cm}^{-1}$ to $\mathrm{C}-\mathrm{O}$ stretching, and $1416 \mathrm{~cm}^{-1}$ to $\mathrm{OH}$ in-plane bending. Trans-C-H outof-plane bend for CA was detected at $974 \mathrm{~cm}^{-1}$. C-H monosubstitution band for phenyl group could be detected at $764 \mathrm{~cm}^{-1}$ and $695 \mathrm{~cm}^{-1}$. On the other hand, the intercalation compound exhibits most of the vibrations assigned to cinnamate, although several vibrations shifted due to interaction between cinnamate anion and the interlayer. In particular, vibrations due to trans $-\mathrm{C}-\mathrm{H}$ out-of-plane bend $\left(973 \mathrm{~cm}^{-1}\right)$ and $\mathrm{C}-\mathrm{H}$ monosubstitution band $\left(769 \mathrm{~cm}^{-1}\right.$ and $\left.682 \mathrm{~cm}^{-1}\right)$. COO ${ }^{-}$stretching of intercalated cinnamate anion overlapped and appeared at 1561 and $1390 \mathrm{~cm}^{-1}$. Highly overlapped $\mathrm{C}=\mathrm{C}$ stretch in pure CA is instead more defined as intercalated cinnamate by showing a strong band at $1642 \mathrm{~cm}^{-1}$. The broad band at $3364 \mathrm{~cm}^{-1}$ is assigned to the $\mathrm{O}-\mathrm{H}$ stretching of vibration of interlayer water molecules. These results indicate that cinnamate anions are present in the sample and were intercalated between positively charged ZLH layers, as indicated by the characteristics of PXRD pattern.

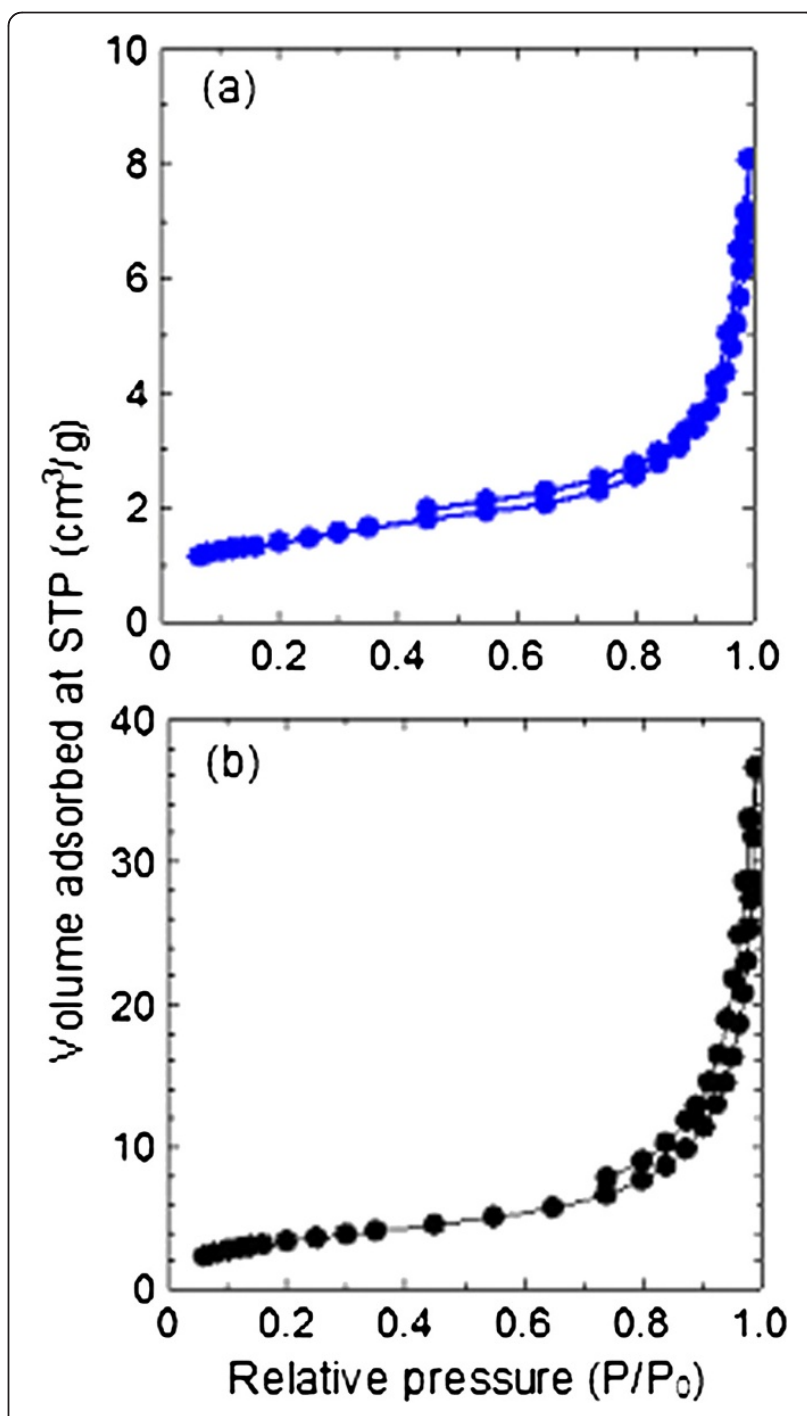

Figure 5 Adsorption-desorption isotherms of $\mathrm{ZnO}$ (a) and ZCA intercalation compound (b). 


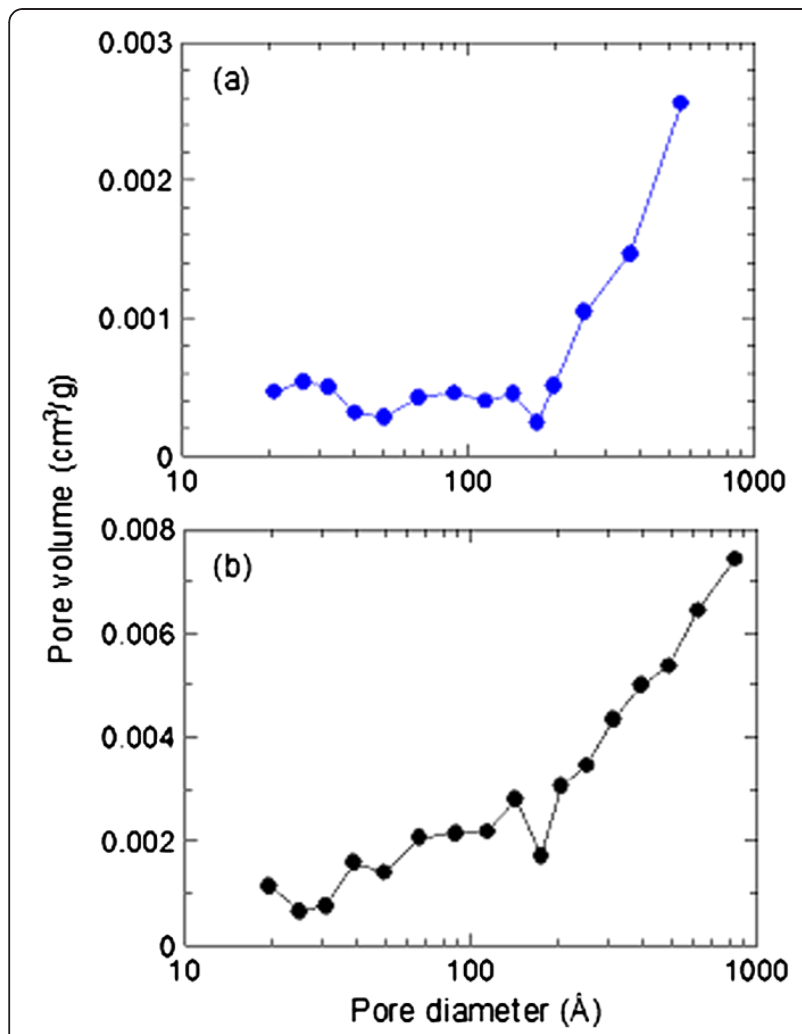

Figure 6 Pore size distribution of $\mathrm{ZnO}$ (a) and ZCA intercalation compound (b).

\section{Surface properties}

FESEM images of pure $\mathrm{ZnO}$ and $\mathrm{ZCA}$ intercalation compound are shown in Figure 4(a) and Figure 4(b), respectively. $\mathrm{ZnO}$ is shown to have a granular structure with various shapes and sizes. The size of $\mathrm{ZnO}$ nanoparticles ranges from 50-600 $\mathrm{nm}$. The nanoparticles of $\mathrm{ZnO}$ are converted to agglomerates of plate-like ZCA particles with non uniform shapes and sizes, in the range of micrometer order. Increase in particle size is evident with the increase of surface area, as recorded in Table 1.

$\mathrm{ZnO}$ has long been used in sunscreen products as it carries a strong capability to absorb UV rays. However, recent findings shows hair follicle allows penetration of nanoparticles up to $320 \mathrm{~nm}$ in size and excitation of $\mathrm{ZnO}$ due to sunlight and household items produces oxygen radical species that plays a role in skin aging and photocarcinogenesis [22-24]. In a way, conversion of $\mathrm{ZnO}$ precursor to particles of ZCA that are bigger in size will prevent penetration into hair follicles.

Figure 5(a) and 5(b) show the nitrogen adsorptiondesorption isotherms of $\mathrm{ZnO}$ and $\mathrm{ZCA}$ intercalation compound, respectively. Both precursor and intercalation compound depicts Type IV isotherm with H3-type hysteresis loop by International Union of Pure and Applied Chemistry (IUPAC) classification. This type of loop is typical for mesoporous materials comprised of agglomerates

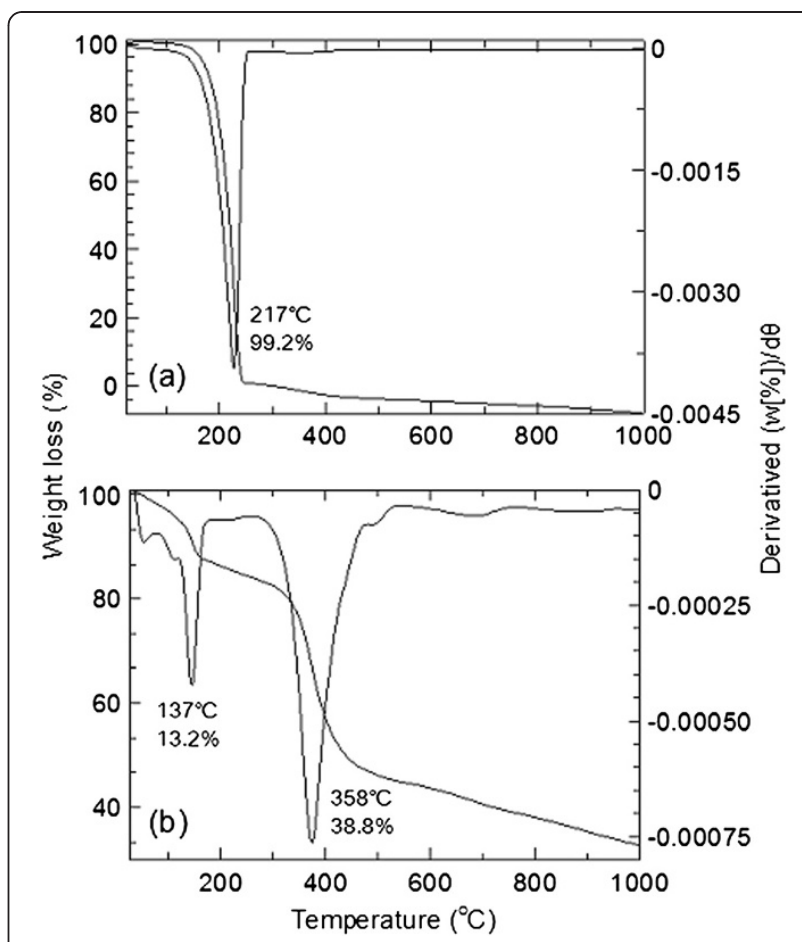

Figure 7 TGA/DTG analyses of CA (a) and ZCA intercalation compound (b).

of plate-like particles with slit shaped pores [25]. $\mathrm{ZnO}$ showed slow adsorbate uptake at relative pressure range of $0.0-0.4$ and reaches the optimum uptake at $8 \mathrm{~cm}^{3} / \mathrm{g}$ while ZCA intercalation compound showed rapid adsorption around relative pressure range, $0.0-0.7$ and reached the maximum adsorption at $37 \mathrm{~cm}^{3} / \mathrm{g}$. Desorption branch for $\mathrm{ZnO}$ is much narrower compared to $\mathrm{ZCA}$. In addition, we recorded an increase in pore size and pore volume from $\mathrm{ZnO}$ to $\mathrm{ZCA}$ intercalation compound as shown in Table 1. These results indicate a modification of pore texture as a result of transformation from $\mathrm{ZnO}$ precursor to

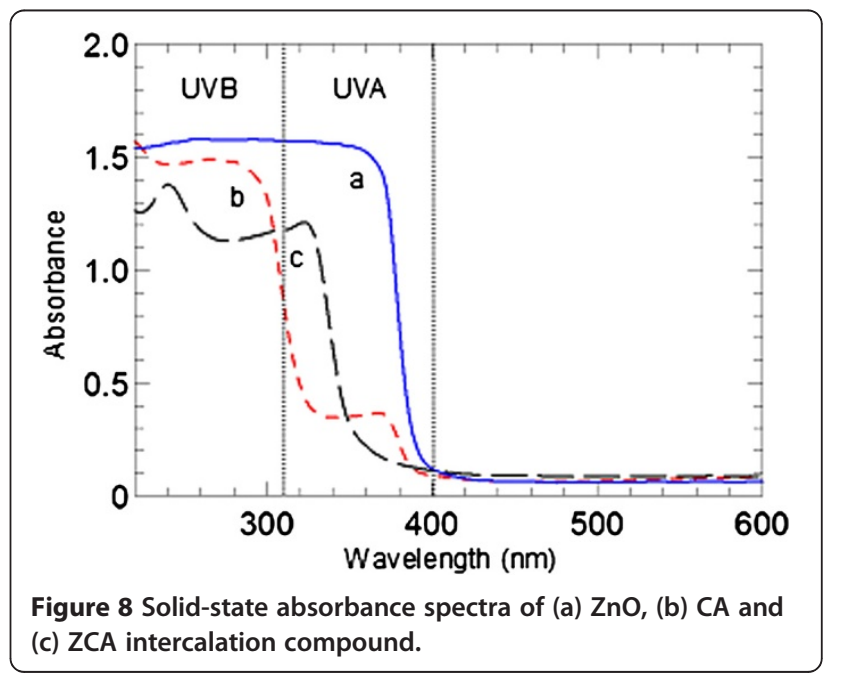




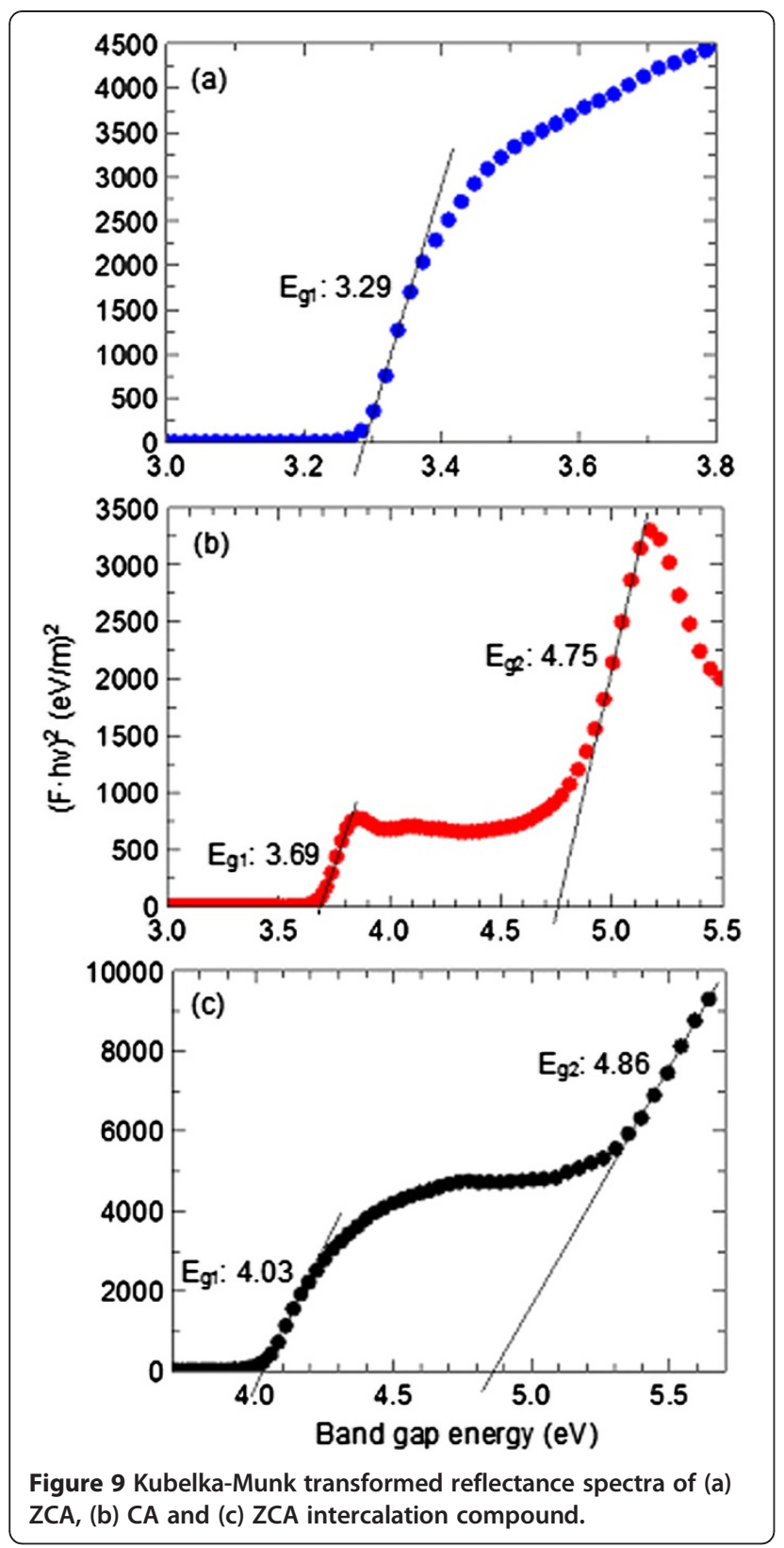

layered intercalation compound. FESEM images show a wide distribution of pores for both $\mathrm{ZnO}$ (Figure 6(a)) and ZCA intercalation compound (Figure 6(b)).

\section{Thermal analysis}

TGA/DTG measurement of cinnamic acid and ZCA intercalation compound is shown in Figure 7. Thermal analysis curves revealed decomposition profile of pure CA occurred at $217^{\circ} \mathrm{C}(99.2 \%)$ in one step while decomposition of ZCA intercalation compound occurred in two steps, the first one is at around $137^{\circ} \mathrm{C}$ (weight loss of $13.2 \%$ ) and the second step is at around $358^{\circ} \mathrm{C}$ (weight loss of $38.8 \%$ ). The first weight loss attributes to removal of physisorbed and interlayer water. The second weight loss corresponds to the decomposition of intercalated cinnamate. This value is close to the estimated value made from elemental analysis of ZCA, in which it was estimated that the percentage loading of cinnamate in ZLH interlayer to be about 40.4\%, as shown in Table 1 . The degradation temperature attributing to cinnamate in the intercalation compound is higher than the decomposition of pure CA. This indicates that the thermal stability of intercalated organic sunscreen cinnamate is enhanced due to the interaction with ZLH host.

\section{Optical properties}

Solid state absorbance spectra of $\mathrm{ZnO}, \mathrm{CA}$, and $\mathrm{ZLH}$ intercalated with cinnamate anions via direct method are shown in Figure 8. ZnO itself is an excellent UV ray absorbent with high absorption ability that covers both UVA and UVB range. Cinnamic acid is white in colour, with the absorbance peaks at around $240 \mathrm{~nm}$ and $325 \mathrm{~nm}$. After intercalation, ZCA intercalation compound showed broadening in absorption range and a shift in absorbance peaks to the higher wavelength region (266-370 $\mathrm{nm}$ ). Decrease in absorption ability of intercalated sunscreen molecules can be attributed to the dilution effect of confinement in metal hydroxide layers. Broadening of absorption range of intercalation compound is due to spatial confinement and host-guest interactions, namely electro-

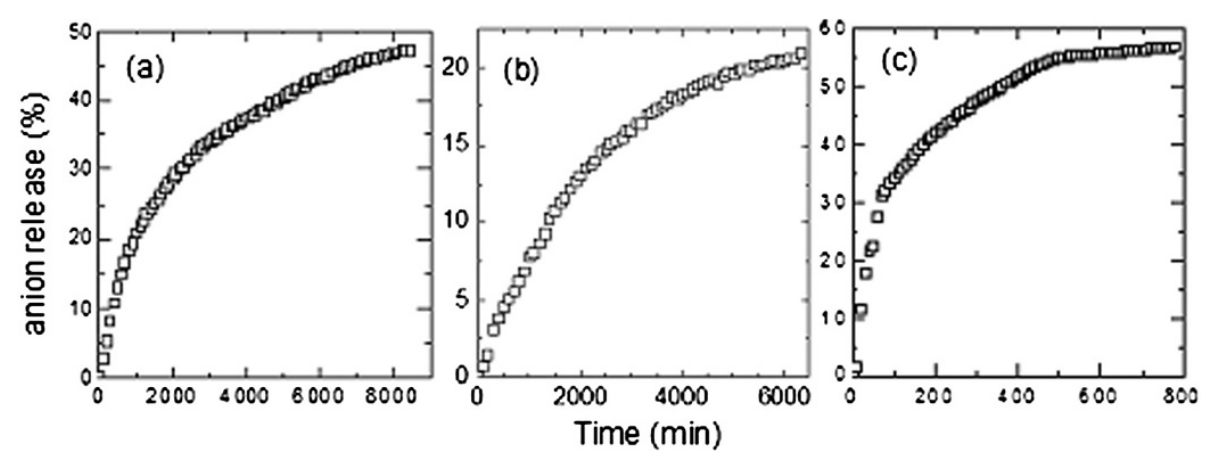

Figure 10 Controlled release of ZCA in deionized water (a), $0.5 \mathrm{~mol} / \mathrm{L} \mathrm{NaCl}$ (b) and pH 5.5 phosphate buffer solution (c). 

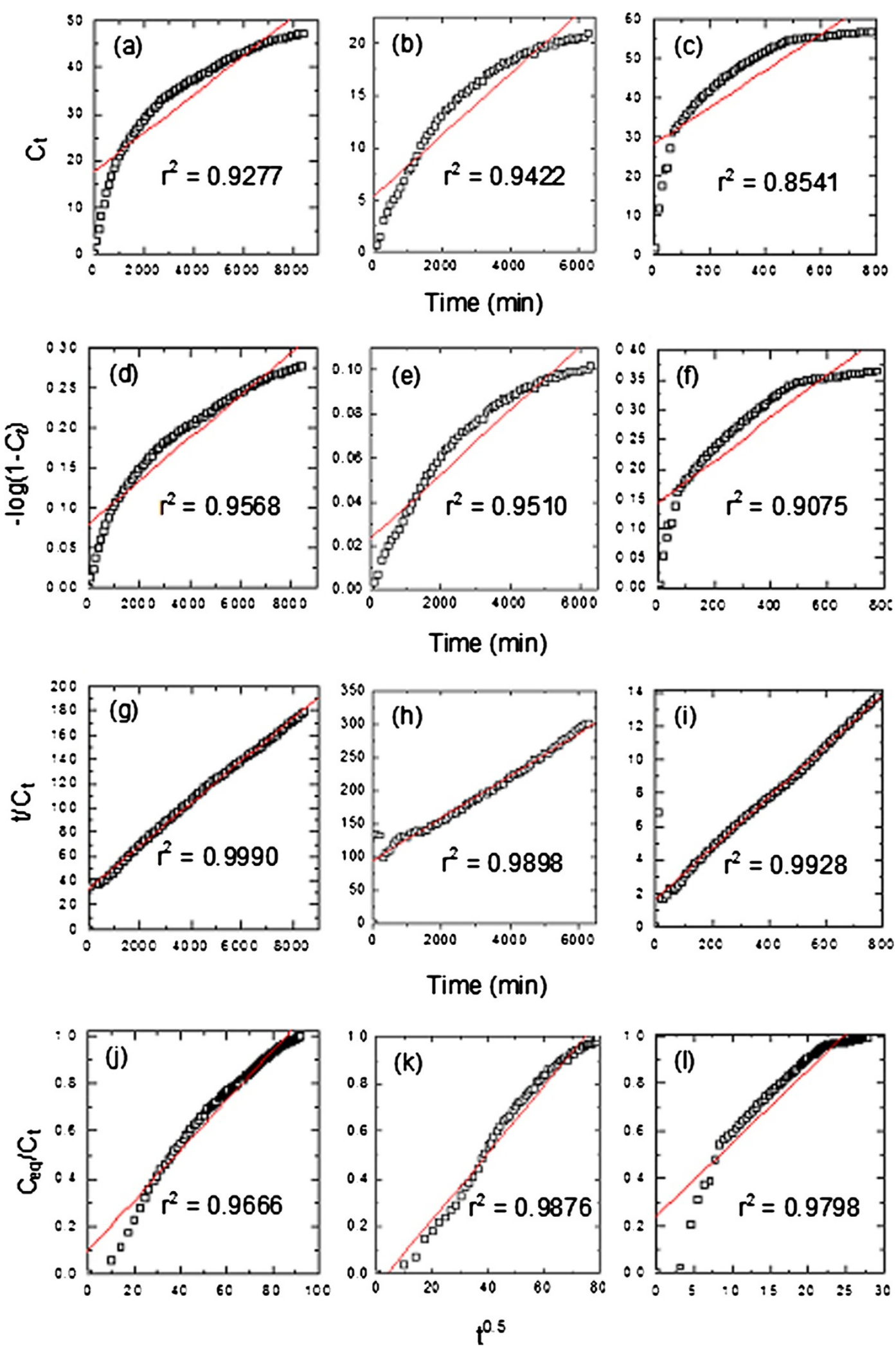

Figure 11 (See legend on next page.) 
(See figure on previous page.)

Figure 11 Fitting the data release of CA from ZCA intercalation compound into media for zeroth-, first-, pseudo second order and parabolic diffusion kinetics for deionized water $(\mathrm{a}, \mathrm{d}, \mathrm{g}$ and $\mathrm{j}$ respectively), $0.5 \mathrm{~mol} / \mathrm{L} \mathrm{NaCl}(\mathrm{b}, \mathrm{e}, \mathrm{h}$ and $\mathrm{k}$ respectively) and $\mathrm{pH} 5.5$ phosphate buffer solution (c, f, i and I respectively).

static attraction, hydrogen bonding and van der Waals forces. Absorption peak shift to the higher wavelength region (red shift) is due to the edge-to-edge association of intercalated organic sunscreen molecules as proposed in Figure 2 [26]. Intermolecular interaction is usually as a result of $\pi-\pi$ interactions or hydrogen bonds. As a result of head-to-tail arrangement of cinnamate molecules, electrostatic attraction occurs between dipoles, which resulted in decreased excitation energy and a shift of absorbance band to the higher wavelength region.

UV-vis diffuse reflectance spectrum was used to obtain the band gap using the Kubelka-Munk equation [27];

$$
(\mathrm{F} \cdot \mathrm{hv})^{2}=A\left(\mathrm{hv}-E_{g}\right)
$$

where F is the Kubelka-Munk, h is Planck's constant, A is a proportionality constant, hv is the photon energy and $E_{g}$ is the band gap energy. Band gap values of samples can be extracted by plotting Eq. 4 as $(\mathrm{F} \cdot \mathrm{hv})^{2}$ against hv and extrapolating the linear region straight line to the $\mathrm{hv}$ intercept. Band gap of $\mathrm{ZnO}, \mathrm{CA}$ and $\mathrm{ZCA}$ intercalation compound was investigated by these measurements, as shown in Figure 9. Low band gap value for $\mathrm{ZnO}$ at 3.29 $\mathrm{eV}$ accounts for its high photocatalytic ability. CA showed more than one band gap, at $3.69 \mathrm{eV}$ and $4.75 \mathrm{eV}$, which is attributed by chromophores in its structure. ZCA intercalation compound maintained the same band gap value as pure $\mathrm{CA}$, as a result of the sunscreen molecule structure being sandwiched between ZLH interlayers. However, the intercalated product showed a shift to a higher band gap at $4.03 \mathrm{eV}$ and $4.86 \mathrm{eV}$. This is due to the effect of stabilization brought upon immobilization of organic molecules in host. Lower band gaps are a result of higher photocatalytic efficiency due to easier transition from the ground state to the excited state. Reduction in photocatalytic activity in sunscreen is encouraged as to counter production of radical oxygen species, a prominent problem with precursor, $\mathrm{ZnO}[28,29]$. Thus, a shift to a lower photocatalytic efficiency shown by ZCA intercalation compound is highly beneficial.

\section{Release behavior of cinnamate anions}

Release profiles of cinnamate from ZLH matrices in deionized water (a), $0.5 \mathrm{~mol} / \mathrm{L} \mathrm{NaCl}$ (b) and $\mathrm{pH} 5.5$ phosphate buffer (c) are shown in Figure 10. Due to anion exchange capability, intercalated cinnamate could be released and exchanged with anions in release media. We proposed circumstances usually came across with sunscreen application to monitor the stability of our formulation in various conditions. Deionized water was chosen as a control while $0.5 \mathrm{~mol} / \mathrm{L} \mathrm{NaCl}$ and $\mathrm{pH} 5.5$ phosphate buffer was respectively chosen to simulate sea water and $\mathrm{pH}$ of skin. The results demonstrated that ZCA reached a saturated released of $47.34 \%$ after 6 days in deionized water, $21.07 \%$ after 4.4 days in $0.5 \mathrm{~mol} / \mathrm{L}$ $\mathrm{NaCl}$ and $57.16 \%$ after $13 \mathrm{~h}$ in pH 5.5 phosphate buffer. These results show that our sunscreen molecule is barely released from ZLH interlayer even after it was immersed within extended period of time while most of it remains entrapped inside the inorganic layered host.

ZLH as host for sunscreen molecules will have some level of release as it has anion exchange capability but the release was shown to be very slow and achieved saturation state at low concentration. These results shows novelty of ZLH use in sunscreen formulation as it provides prolonged UV protection as well as prevention of UV ray absorbent molecules photodegradation into toxic degradation products.

\section{Release kinetics of cinnamate from ZCA intercalation compound}

Kinetic release of cinnamate from ZCA intercalation compound was investigated using various kinetic models; zeroth- (Eq. 5) [30], first- (Eq. 6) [31], parabolic diffusion (Eq. 7) [32] and pseudo-second order kinetics (Eq. 8) [33]. The equations are as given below, where $c$ is a constant, $C_{e q}$ and $C_{t}$ is the concentration of anion at equilibrium and time $t$, respectively.

$$
\begin{aligned}
& C_{t}=k t+c \\
& -\log \left(1-C_{t}\right)=k t \\
& C_{t} / C_{e q}=c+k t^{0.5} \\
& t / C_{t}=1 / k_{2} C_{e q}{ }^{2}+\left(1 / q_{e}\right) t
\end{aligned}
$$

The plots are given in Figure 11. As evident with the values of correlation coefficient, $r^{2}$ in Table 2, the release of cinnamate anion from ZLH interlayer follows the pseudo-second order kinetic. As a result of the fitting, we calculated that the time taken for cinnamate release to be half of accumulated release, $t_{1 / 2}$ value, to be 1924 $\mathrm{min}, 2974 \mathrm{~min}$ and $110 \mathrm{~min}$ for release in deionized water, $0.5 \mathrm{~mol} / \mathrm{L} \mathrm{NaCl}$ and $\mathrm{pH} 5.5$ phosphate buffer solution, respectively. The $t_{1 / 2}$ value could be summarized in the order of; phosphate buffer $>$ deionized water $>0.5$ $\mathrm{mol} / \mathrm{L} \mathrm{NaCl}$. 
Table 2 Correlation coefficient, rate constant and half time obtained by fitting the release data of cinnamate from ZCA intercalation compound into various media using zeroth-, first-, parabolic diffusion and pseudo-second order kinetic models

\begin{tabular}{|c|c|c|c|c|c|c|c|}
\hline \multirow[b]{2}{*}{ Media } & \multirow[b]{2}{*}{$\begin{array}{l}\text { Saturated } \\
\text { release } \\
(\%)\end{array}$} & \multicolumn{4}{|c|}{ Correlation coefficient, $r^{2}$} & \multirow{2}{*}{$\begin{array}{c}\text { Rate } \\
\text { constant } \\
\text { of } \\
\text { pseudo } \\
\text { second } \\
\text { order, } k \\
\left(\mathrm{~L} \mathrm{mg}{ }^{-1}\right. \\
\left.\text { min }^{-1}\right)\end{array}$} & \multirow{2}{*}{$\begin{array}{c}t_{1 / 2} \text { of } \\
\text { pseudo } \\
\text { second } \\
\text { order } \\
(\mathrm{min})\end{array}$} \\
\hline & & Zeroth order & First order & Parabolic diffusion & Pseudo-second order & & \\
\hline Deionized water & 47.34 & 0.9277 & 0.9568 & 0.9666 & 0.9990 & $9.09 \times 10^{-6}$ & 1924 \\
\hline $0.5 \mathrm{~mol} / \mathrm{L} \mathrm{NaCl}$ & 21.07 & 0.9422 & 0.9510 & 0.9876 & 0.9898 & $1.07 \times 10^{-5}$ & 2974 \\
\hline Phosphate buffer pH 5.5 & 57.16 & 0.8541 & 0.9075 & 0.9798 & 0.9928 & $1.38 \times 10^{-4}$ & 110 \\
\hline
\end{tabular}

Zeroth order: $C_{t}=k t+c$, first order: $-\log \left(1-C_{t}\right)=k t+c$, parabolic diffusion: $C_{t} / C_{e q}=c+k t^{0.5}$, pseudo second order: $t / C_{t}=1 / k_{2} C_{e q}^{2}+\left(1 / q_{\mathrm{e}}\right) t$.

Notes: $c=$ a constant; $C_{e q}=$ concentration of anion at equilibrium; $C_{t}=$ concentration of anion at time $t$.

Release rate of the anion from the ZLH interlayer is influenced by the affinity of available anions in the media. The presence of carbonate, an anion known to have the strongest affinity towards ZLH interlayer, in deionized water was responsible for relatively fast and high accumulated release. Low accumulated release and slow release rate in $0.5 \mathrm{~mol} / \mathrm{L} \mathrm{NaCl}$ is attributed to low ion exchange affinity of chloride towards interlayer of ZLH. Phosphate buffer solution consists of phosphate, carbonate and chloride while $0.5 \mathrm{~mol} / \mathrm{L} \mathrm{NaCl}$ contains only chloride. Release rate and accumulated release will be elevated with the presence of phosphate combined with other anions due to multiple hydrolysis of phosphate $[34,35]$. ZCA was found to have the highest accumulated release and fastest rate in skin $\mathrm{pH}$ simulation. Nonetheless, ZCA reached a saturated release in phosphate buffer after prolonged time (13 h) in comparison to actual use of sunscreen product. Furthermore, $\mathrm{pH} 5.5$ phosphate buffer only reproduces skin $\mathrm{pH}$ value and not the real physiological conditions.

\section{Effect of ZLH-sunscreen intercalation compound on cell viability}

The biomedical applications of synthesized nanoparticles are currently attracting much research interest. The progress and application of nanotechnology enhances the quality of our human lives but also results in a health burden. Major issue in determining the efficacy of these materials is assessing their potential cellular toxicity either due to their inherent chemical composition/structure or as a consequence of their nanoscale biophysical properties [36]. In order to evaluate directly if these synthesized nanoparticles were in a range to be physiologically harmful to human skin, we tested their effects on human dermal fibroblasts using a cell viability biological assays.

Human dermal fibroblast cells were exposed to samples at various gradient concentrations of $0.781,1.562$,
$3.125,6.25,12.5,25$ and $50 \mu \mathrm{g} / \mathrm{mL}$ for $24 \mathrm{~h}$, and cell cytotoxicity was evaluated by MTT assay (Figure 12). ZCA intercalation compound at the concentration from 0.781 to $12.5 \mu \mathrm{g} / \mathrm{mL}$ did not show any noticeable reduction in cell viability. Cells exposed to 25 and $50 \mu \mathrm{g} / \mathrm{mL}$ of intercalation compound showed around 30\% and greater than $50 \%$ reduction, respectively in cell viability (Figure 12).

We found that synthesized intercalation compound exposure effectively reduced cell viability of human dermal fibroblasts at concentration $25 \mu \mathrm{g} / \mathrm{mL}$ and above. Based on this finding we suggest that intercalation compound dosage up to $12.5 \mu \mathrm{g} / \mathrm{mL}$ did not produce any cytotoxicity. Hence, further studies should focus at the range of the concentration not more than that $25 \mu \mathrm{g} / \mathrm{mL}$, to develop the cosmetic product using the particular nanocarrier. At a concentration higher than $25 \mu \mathrm{g} / \mathrm{mL}$, substantial study to focus on dermal toxicity with experimental animals for translational studies to provide systematic molecular mechanisms for biomedical application.

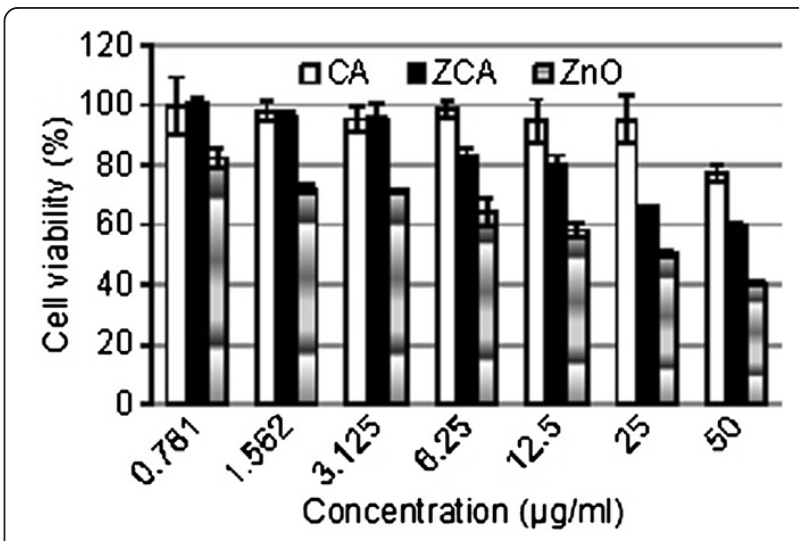

Figure 12 Cell viability of HDF cells after 24 hours treatment with CA, ZCA and ZnO. The data were presented as mean \pm S.D. 


\section{Conclusions}

In the present work, organic UV-ray absorbing active agent, cinnamate anion has been successfully intercalated into $\mathrm{ZLH}$ interlayers spaces from zinc oxide precursor to generate ZCA intercalation compound with a basal spacing of $23.9 \AA$ to accommodate cinnamates in a bilayer arrangement. ZCA intercalation compound retained excellent absorption capacity in the UV region of pure CA but with slight shift in absorption peaks and broadened absorption range due to arrangement in host and host-guest interactions. Retention of cinnamate in ZLH interlayers was tested with various media to show slow release and saturated release at a very low concentration. Hence it was demonstrated that the resulting material is suitable to be used as sunscreen with long term UV protection effect.

\section{Abbreviations}

ZLH: Zinc layered hydroxide; CA: Cinnamic acid; ZnO: Zinc oxide; HDF: Human dermal fibroblast; UV: Ultraviolet; LHS: Layered hydroxide salt; ZCA: Cinnamate- zinc layered hydroxide intercalation compound; BET: Brunauer-Emmett-Teller; BJH: Barrett-Joyner-Helenda.

\section{Competing interests}

The authors declare that they have no competing interests.

\section{Authors' contributions \\ SMNM produced samples, performed data analysis and interpretation and drafted the manuscript; MZH conceived the study, participated in the design and coordination of scientific teams and assisted to draft the manuscript; SHS assisted in the design of cinnamate retention study; SF participated in the design of cytotoxicity study; PA carried out the MTT assay and interpretation of cytotoxicity results; TYH assisted in X-ray diffraction and interpretation. All authors read and approved the final manuscript.}

\section{Authors' information}

Prof. Dr. Mohd Zobir Hussein is a Professor of Chemistry in Institute of Advanced Technology (ITMA), Universiti Putra Malaysia. His major research areas include layered organic-inorganic nanohybrid for gene and drug delivery, nanoparticles and nanostructured materials, their design, synthesis and applications. He is a prolific author and has contributed to more than 200 technical papers. He is the assignor of 1 granted patent on the preparation method of nanomaterial for controlled release formulation and co-assignor of another 2 granted patents.

\section{Acknowledgements}

This work was financially supported by the Ministry of Higher Education (MOHE) of Malaysia under ERGS/1/11/STG/UPM/01/01/18. One of the authors (SMNM) would like to thank Universiti Putra Malaysia for Graduate Research Fellowship (GRF).

\footnotetext{
Author details

${ }^{1}$ Material Synthesis and Characterization Laboratory, Institute of Advanced Technology (ITMA), Universiti Putra Malaysia, Serdang, Selangor 43400 UPM, Malaysia. ${ }^{2}$ Faculty of Applied Sciences, Universiti Teknologi MARA, Shah Alam, Selangor 40450 UiTM, Malaysia. ${ }^{3}$ Department of Human Anatomy, Faculty of Medicine and Health Sciences, Universiti Putra Malaysia, Serdang, Selangor 43400 UPM, Malaysia. ${ }^{4}$ Laboratory of Vaccines and Immunotherapeutics, Institute of Bioscience, Universiti Putra Malaysia, Serdang, Selangor 43400 UPM, Malaysia. ${ }^{5}$ Centre of Excellence for Catalysis Science and Technology, Faculty of Science, Universiti Putra Malaysia, Serdang, Selangor 43400 UPM, Malaysia.
}

Received: 13 December 2012 Accepted: 25 January 2013 Published: 6 February 2013

\section{References}

1. Lucas R, McMichael T, Smith W, Armstrong B: Solar ultraviolet radiation: Global burden of disease from solar ultraviolet radiation. Geneva: Switzerland; 2006.

2. Perioli L, Ambrogi V, Bertini B, Ricci M, Nocchetti M, Latterini L, Rossi C: Anionic clays for sunscreen agent safe use: Photoprotection, photostability and prevention of their skin penetration. Eur J Pharmaceut Biopharmaceut 2006, 62:185-193.

3. Cursino ACT, Gardolinski JEFC, Wypych F: Intercalation of anionic organic ultraviolet ray absorbers into layered zinc hydroxide nitrate. J Colloid Interf Sci 2010, 347:149-55.

4. Sun W, He Q, Luo Y: Synthesis and properties of cinnamic acid series organic UV ray absorbents-interleaved layered double hydroxides. Mater Lett 2007, 61:1881-1884.

5. Arizaga GGC, Satyanarayana KG, Wypych F: Layered hydroxide salts: Synthesis, properties and potential applications. Solid State Ion 2007, 178:1143-1162

6. Hussein MZ, Ali SHA, Zainal Z, Hakim MN: Development of antiproliferative nanohybrid compound with controlled release property using ellagic acid as the active agent. Int J Nanomed 2011, 6:1373-1383.

7. Ali SHA, Al-Qubaisi M, Hussein MZ, Zainal Z, Hakim MN: Preparation of hippurate-zinc layered hydroxide nanohybrid and its synergistic effect with tamoxifen on HepG2 cell lines. Int J Nanomed 2011, 6:3099-3111.

8. Hussein MZ, Rahman NSSA, Sarijo SH, Zainal Z: Herbicide-intercalated zinc layered hydroxide nanohybrid for a dual-guest controlled release formulation. Int J Mol Sci 2012, 13:7328-7342.

9. Kandare E, Chigwada G, Wang D, Wilkie CA, Hossenlopp JM: Probing synergism, antagonism, and additive effects in poly(vinyl ester) (PVE) composites with fire retardants. Polym Degrad Stab 2006, 91:1209-1218.

10. Boshkov N, Petrov K, Vitkova S, Raichevsky G: Galvanic alloys Zn-Mncomposition of the corrosion products and their protective ability in sulfate containing medium. Surf CoatTechnol 2005, 194:276-282.

11. Rouba S, Rabu P, Drillon M: Synthesis and characterization of new quasione-dimensional $\mathrm{Mn}(\mathrm{II})$ hydroxynitrates $\left(\mathrm{Mn}_{x} \mathrm{Zn}_{1-x}\right)(\mathrm{OH})\left(\mathrm{NO}_{3}\right) \mathrm{H}_{2} \mathrm{O}$ $(x=0.53,1.00)$. J Solid State Chem 1995, 118:28-32.

12. Stählin W, Oswald HR: The crystal structure of zinc hydroxide nitrate, $Z_{5}$ $(\mathrm{OH})_{8}\left(\mathrm{NO}_{3}\right)_{2} \cdot 2 \mathrm{H}_{2} \mathrm{O}$. Acta Crystallogr Sect B 1970, 26:860-863.

13. Cursino ACT, Mangrich AS, da Costa Gardolinski JEF, Mattoso N, Wypych F: Effect of confinement of anionic organic ultraviolet ray absorbers into two-dimensional zinc hydroxide nitrate galleries. J Braz Chem Soc 2011, 22:1183-1191

14. Rajamathi M, Kamathi PV: Urea hydrolysis of cobalt(II) nitrate melts: synthesis of novel hydroxides and hydroxynitrates. Inter J Inorg Mater 2001, 7:901-906.

15. Hoyo CD: Layered double hydroxides and human health: an overview. Appl Clay Sci 2007, 36:103-121.

16. Xingfu Z, Zhaolin H, Yiqun F, Su C, Weiping D, Nanping X: Microspheric organization of multilayered $\mathrm{ZnO}$ nanosheets with hierarchically porous structures. J Phys Chem C 2008, 112:11722-11728.

17. Miao J, Xue M, Itoh H, Feng Q: Hydrothermal synthesis of layered hydroxide zinc benzoate compounds and their exfoliation reactions. J Mater Chem 2006, 16:474-480.

18. Degen A, Kosec M: Effect of $\mathrm{pH}$ and impurities on the surface charge of zinc oxide in aqueous solution. J Eur Ceram Soc 2000, 20:667-673.

19. Bang S, Lee S, Ko Y, Park J, Shin S, Seo H, Jeon H: Photocurrent detection of chemically tuned hierarchical $\mathrm{ZnO}$ nanostructures grown on seed layers formed by atomic layer deposition. Nanoscale Res Lett 2012, 7:1-11.

20. Marangoni R, Ramos LP, Wypych F: New multifunctional materials obtained by the intercalation of anionic dyes into layered zinc hydroxide nitrate followed by dispersion into poly(vinyl alcohol) (PVA). J Colloid Interface Sci 2009, 330:303-309.

21. Muñoz-Espí R, Chandra A, Wegner G: Crystal perfection in zinc oxide with occluded carboxyl-functionalized latex particles. Cryst Growth Des 2007, 7:1584-1589.

22. Baek M, Kim MK, Cho HJ, Lee JA, Yu J, Chung HE, Choi SJ: Factors influencing the cytotoxicity of zinc oxide nanoparticles: particle size and surface charge. J Phys Conf Ser 2011, 304:1-7.

23. Tran DT, Salmon R: Potential photocarcinogenic effects of nanoparticle sunscreens. Australas J Dermatol 2010, 52:1-6.

24. Dechsakulthorn F, Hayes A, Bakand S, Joeng L, Winder C: In vitro cytotoxicity assessment of selected nanoparticles using human skin fibroblasts. Alternatives to Animal Testing and Experimentation 2008, 14:397-400. 
25. Zhi $Y$, Li Y, Zhang $\mathrm{Q}$, Wang $\mathrm{H}$ : ZnO nanoparticles immobilized on flaky layered double hydroxides as photocatalysts with enhanced adsorptivity for removal of acid red G. Langmuir 2010, 26:15546-15553.

26. Marangoni R, Taviot-Guého C, Illaik A, Wypych F, Leroux F: Organic inorganic dye filler for polymer: blue-coloured layered double hydroxides into polystyrene. J Colloid Interface Sci 2008, 326:366-373.

27. Ahmed AAA, Talib ZA, Hussein MZ, Zakaria A: Zn-Al layered double hydroxide prepared at different molar ratios: Preparation,

characterization, optical and dielectric properties. I Solid State Chem 2012, 191:271-278.

28. Ng KW, Khoo SPK, Heng BC, Setyawati MI, Tan EC, Zhao X, Xiong S, Fang W, Leong DT, Loo JSC: The role of the tumor suppressor p53 pathway in the cellular DNA damage response to zinc oxide nanoparticles. Biomaterials 2011, 32:8218-8225.

29. Xu M, Fujita D, Kajiwara S, Minowa T, Li X, Takemura T, Iwai H, Hanagata N: Contribution of physicochemical characteristics of nano-oxides to cytotoxicity. Biomaterials 2010, 31:8022-8031.

30. Costa P, Lobo JMS: Modeling and comparison of dissolution profiles. Eur J Pharm Sci 2001, 13:123-133.

31. Singh J, Gupta S, Kaur H: Prediction of in vitro drug release mechanisms from extended release matrix tablets using SSR $/ R^{2}$ technique. Trends Applied Sci Res 2011, 6:400-409.

32. Kodama T, Harada Y, Ueda M, Shimizu K, Shuto K, Komarneni S: Selective exchange and fixation of strontium ions with ultrafine $\mathrm{Na}-4$-mica. Langmuir 2001, 17:4881-4886.

33. Ling L, He J, Wei M, Evans DG, Duan X: Uptake of chloride ion from aqueous solution by calcined layered double hydroxides: equilibrium and kinetic studies. Wat Res 2006, 40:735-743.

34. Hussein MZ, Jaafar AM, Yahaya AH, Zainal Z: The effect of single, binary and ternary anions of chloride, carbonate and phosphate on the release of 2,4-dichlorophenoxyacetate intercalated into the $\mathrm{Zn}$-Al-layered double hydroxide nanohybrid. Nanoscale Res Lett 2009, 4:1351-1357.

35. Kugelmass IN: The determination of the tertiary dissociation constant of phosphoric acid. Biochem 1929, 38:587-592.

36. Derfus AM, Chan WCW, Bhatia SN: Probing the cytotoxicity of semiconductor quantum dots. Nano Lett 2004, 4:11-18.

doi:10.1186/1752-153X-7-26

Cite this article as: Mohsin et al: Synthesis of (cinnamate-zinc layered hydroxide) intercalation compound for sunscreen application. Chemistry Central Journal 2013 7:26.

\section{Publish with ChemistryCentral and every scientist can read your work free of charge \\ "Open access provides opportunities to our colleagues in other parts of the globe, by allowing anyone to view the content free of charge." \\ W. Jeffery Hurst, The Hershey Company. \\ - available free of charge to the entire scientific community \\ - peer reviewed and published immediately upon acceptance \\ - cited in PubMed and archived on PubMed Central \\ - yours - you keep the copyright \\ Submit your manuscript here: \\ http://www.chemistrycentral.com/manuscript/<smiles>c1ccccc1</smiles> \\ Chemistry Central}

